\title{
Management options for reducing maize yield gaps in contrasting sowing dates
}

\author{
Lucas N. Vitantonio-Mazzini ${ }^{\mathrm{a}, *}$, Lucas Borrás ${ }^{\mathrm{a}}$, Lucas A. Garibaldi ${ }^{\mathrm{b}}$, Diego H. Pérez ${ }^{\mathrm{c}}$, \\ Santiago Gallo ${ }^{c}$, Brenda L. Gambin ${ }^{a}$ \\ ${ }^{a}$ IICAR - CONICET, Concejo Nacional de Investigaciones Científicas y Técnicas, Facultad de Ciencias Agrarias, Universidad Nacional de Rosario, Campo Experimental \\ Villarino S/N, S2125ZAA, Zavalla, Prov. de Santa Fe, Argentina \\ b Instituto de Investigaciones en Recursos Naturales, Agroecología y Desarrollo Rural (IRNAD), Sede Andina, Universidad Nacional de Río Negro (UNRN), Mitre 630, \\ CP8400, San Carlos de Bariloche, Río Negro, Argentina \\ ${ }^{\mathrm{c}}$ AACREA, Asociación Argentina de Consorcios Regionales de Experimentación Agrícola, C1041AAZ, Ciudad Autónoma de Buenos Aires, Argentina
}

\section{A R T I C L E I N F O}

\section{Keywords:}

Sowing date

Water table

Stand density

Fertilizer management

Multi-model inference

\begin{abstract}
A B S T R A C T
Optimizing grain production implies defining the best management practices for a set of particular environments. Argentinean farmers in the central temperate region are sowing maize at two contrasting sowing dates (September to October and December), exposing their crops to very different growing environments. We tested the influence of management and environmental variables affecting maize yield at early (ES) or late (LS) sowings. Our objectives were to (i) determine the most relevant management and environmental yield predictors for ES and LS, (ii) quantify the magnitude of their effects, and (iii) explore potential yield increments after optimizing crop management within each sowing. We conducted 91 on-farm multi-environment trials during six years (2010-2016) around the central temperate region, and analyzed 13 management and environmental variables.

The most relevant environmental predictors (relative importance $>0.50$ ) for both sowing dates included presence of a water table at sowing, rainfall during the crop cycle, and their interactions. Presence of a water table had a positive or negative effect for ES or LS, respectively. Management yield predictors varied depending on the sowing date. Stand density, N and S availability were important yield predictors at ES, while fungicide use, soil P, and N availability were the most relevant ones at LS. Farmers can increase yield at each sowing date by optimizing these management practices. Optimizing stand density and $\mathrm{N}$ availability in ES can have a $\sim 3,053 \mathrm{~kg} \mathrm{ha}^{-1}$ effect, while fungicide use in LS can increase yield by $\sim 1040 \mathrm{~kg} \mathrm{ha}^{-1}$. Determining the adequate sowing date based on the presence of a water table at sowing can have a $\sim 1000 \mathrm{~kg} \mathrm{ha}^{-1}$ effect. Our results described specific management options for reducing yield gaps and optimize maize production across contrasting sowing dates.
\end{abstract}

\section{Introduction}

Global food agricultural production pursuits higher crop yields with less environmental impact (Foley et al., 2011). To obtain higher yields farmers need to adequate management decisions to their particular environmental context (Hatfield and Walthall, 2015). This requires a detailed understanding of complex management $\mathrm{x}$ environment interactions. A recent study reported that today the maize water limited yield gap for Argentina is around $41 \%$ (or $4810 \mathrm{~kg} \mathrm{ha}^{-1}$ ) (Aramburu Merlos et al., 2015).
Argentinean farmers in the central temperate region are sowing their maize crops at two contrasting dates. Early sowing dates (ES) take place during September-October, while late sowing dates (LS) take place around December. While ES is traditional for the region, LS became important more recently following the introduction of insect resistant (i.e., Bt) corn in late 1990s. These contrasting sowing dates expose the crop to different scenarios in terms of temperature, solar radiation, and water availability (Maddonni, 2012). Late sowing dates locate the critical flowering period for yield definition (Andrade et al., 1999) under conditions of higher rainfall probability, lower evaporative

\footnotetext{
Abbreviations: AIC, Akaike's information criterion; BIC, Bayesian's information criterion; ES, early sowing; LS, late sowing; METs, multi-environment trials; ML, maximum likelihood; MMI, multi-model inference; REML, restricted maximum likelihood; RI, relative importance

* Corresponding author.

E-mail address: lucas.vitantonio@unr.edu.ar (L.N. Vitantonio-Mazzini).
} 
demand, and lower radiation levels when compared to ES. In consequence, yield potential for LS is, on average, lower. However, LS are known to confer higher yield stability (Otegui et al., 1996; Mercau and Otegui, 2014), especially in lower quality soils. Based on this, half of the maize planted in the central temperate region is currently sown in each sowing date (PAS. Panorama Agrícola Semanal, 2018).

While farmers need to decide which sowing date is the optimum one for each particular field paddock, there is also a large level of uncertainty when comparing the relevance of specific management options for each sowing date. Stand density and nitrogen $(\mathrm{N})$ fertilization are known to be important management decisions for ES (Cirilo and Andrade, 1994; Calviño et al., 2003) and LS (Caviglia et al., 2014; Gambin et al., 2016; Coyos et al., 2018; Maltese et al., 2019). In LS, crop protection is supposed to be more relevant due to the higher disease pressure (Abdala et al., 2018). Water availability appears among environmental important variables in ES (Podestá et al., 1999; Maddonni, 2012; Florio et al., 2014), while its yield effect in LS is limited (Gambin et al., 2016). Relevant predictors, however, have not been analyzed in a comparative way for ES and LS. This can provide information to help farmers determine the sowing date that is more convenient to particular field paddocks, and to understand the value of specific management options in each sowing date. For this, we conducted a study comparing both sowing dates.

There are several ways to generate information for optimizing grain production. One is field experimentation, designed to answer a particular question related to a management variable. For example, experiments under different stand densities to define optimum stand density, or experiments with different $\mathrm{N}$ application rates to define optimum N doses (Williams et al., 1968; Cerrato and Blackmer, 1990). Experiments need to be replicated during several years and/or sites to evaluate the consistency of results or explore potential management $\mathrm{x}$ environment interactions, complicating results interpretation and extrapolation. Although very useful, this approach is time and cost-consuming, and results are usually limited to those particular environments and explored genotypes. Another option is in silico experimentation (Boote et al., 1996; Passioura, 1996), which allows exploring different genotype $\mathrm{x}$ management $\mathrm{x}$ environment combinations as long as the model structure and validation allows it (Hammer et al., 2014). Simulation models are subject to error and results always have a level of uncertainty, and field experimentation is always needed to validate promising management options.

An intermediate approach involves the use of multi-environment trials (METs), or also called yield comparison trials. They consist in field trials where a group of genotypes are grown across numerous environments or locations, representing a specific target region. Although the main interest of these experiments relies on the performance of genotypes in a target region of environments (DeLacy et al., 1996), information about specific management and environmental variables are usually available. Each trial is generally managed by the farmer in terms of particular sowing date, fertilizer management, and stand density, thus providing different combinations of genotype $\mathrm{x}$ management $\mathrm{x}$ environment, and a big potential for exploring the influence of different management and environmental variables (Gambin et al., 2016).

In the present manuscript, we studied the influence of different management and environmental variables at contrasting sowing dates in the central temperate region of Argentina. Our objectives were to (i) define the most relevant management and environmental yield predictors for early and late sowings, (ii) quantify the magnitude of their effects, and (iii) explore potential yield increments after management optimization in each sowing date. Given that LS are more recent, we expected yield gains would be more important in LS compared to ES after management optimization (based on yield increments).

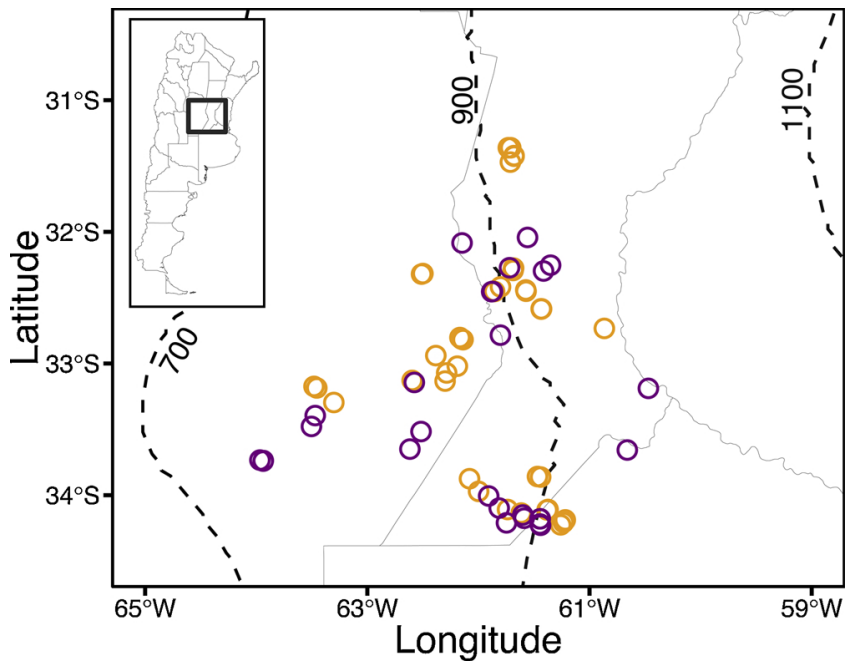

Fig. 1. Map of central Argentina showing the location of the environments tested. Empty yellow circles indicate the 58 trials with an early sowing date, empty purple circles show the 33 trials with a late sowing date. Solid lines show province boundaries, and broken lines describe annual rainfall isohyets (700, 900, and $1100 \mathrm{~mm} \mathrm{yr}^{-1}$ ) based on data from 1970-2000. (For interpretation of the references to colour in this figure legend, the reader is referred to the web version of this article).

\section{Materials and methods}

\subsection{Study system}

Genotype yield comparison trials for ES and LS were conducted in farms grouped within CREA Sur de Santa Fe from the Argentine Association of Regional Consortiums for Agricultural Experimentation (AACREA). Trials included different locations across central Argentina (Fig. 1) during six growing seasons (from 2010/2011-2015/2016, referred as 2010-2015). In total we had 58 and 33 trials for ES and LS, respectively. There was no clear spatial distribution when sowing dates were compared based on a heatmap, and visually evident in Fig. 1. The term "site" will be used herein to define the combination of a particular experiment in a given sowing date, location, and year. All farm fields used for trials were managed under no-tillage for a minimum of 15 years, and received no irrigation.

A total of ninety-one maize hybrids from eighteen different seed companies were tested (Table S1). Genotypes used in ES and LS were not always the same, and only a proportion of them appeared in both sowing dates. Genotypic average relative maturity was 120 and 123 for all early and late sowings, respectively, and ranged from 116 to 128 and 116-129 in early and late sowings, respectively (Table S1). This showed relative maturities were basically the same when comparing sowing dates. Trials always had a randomized complete block design with two or three replicates. Plot size ranged from 6 to 8 rows wide and from 200 to $240 \mathrm{~m}$ length. Inter-row spacing was always $0.52 \mathrm{~m}$.

Each individual trial was managed by the farmer in terms of sowing date, phosphorous (P) management, nitrogen (N) management, sulfur (S) management, stand density, and cropped using his commercial technology (planter, harvesting). This makes the analyzed trials representative of the maize production system in the region. All experiments were rainfed, and weeds and insects were chemically controlled using standard practices. Soils are predominantly deep sandy loams (Typic Hapludoll, Entic Hapludoll, and Haplustoll) and shallow clay soils (Aquic Argiudoll and Argialboll) (Soil Survey Staff, 2014). Major soil types represent the most commonly used for maize production on the region (types I, II, III; Klingebiel and Montgomery, 1961). Individual experiments were entirely fitted within a field portion having uniform soil characteristics, based on soil taxonomy maps, and similar 
management of previous crops.

In every trial, soil samples until $60 \mathrm{~cm}$ depth were taken before sowing to determine initial soil proprieties. Soil test included percentage of organic matter $(\mathrm{OM})$ and amount of $\mathrm{P}$ and $\mathrm{S}(\mathrm{ppm})$ were determined until $20 \mathrm{~cm}$ depth, and $\mathrm{N}-\mathrm{NO}_{3}$ was determined until $60 \mathrm{~cm}$ depth. Organic matter was determined by semi-micro technique (Walkley and Black, 1934), and $\mathrm{P}, \mathrm{S}$, and $\mathrm{N}-\mathrm{NO}_{3}$ was determined by spectrophotometry. The amount of $\mathrm{P}, \mathrm{S}$, and $\mathrm{N}$ applied in each trial was determined by each individual farmer independently, and based on soil analysis, expected yield, and costs.

Soil available water content was determined at each site to $1 \mathrm{~m}$ depth by gravimetric method (Black, 1965). It was converted to mm $\mathrm{ha}^{-1}$ based on soil apparent density. Apparent soil density was taken from maps provided by the Argentinean federal agricultural agency INTA (GeoInta, http://visor.geointa.inta.gob.ar/) for each site. Water table at sowing was indicated when present at sowing, until $2 \mathrm{~m}$ depth. Rainfall during the crop cycle from sowing to physiological maturity was recorded at each site.

Grain yield data is presented with $14 \%$ moisture. Harvest was done with a commercial combine harvester. Yield of each replicate plot was obtained weighting tractor trailer grain tanks with sensors. Analyzed sites showed no major weeds, lodging, or disease problems. The first winter killing frost was always latter than physiological maturity for all trials.

\subsection{Explored predictor variables}

Our interest was to identify management and environmental variables that can latter help predict yield for the two common sowing dates of our region. For this, we first explored the potential influence of different predictors on yield. These predictors included quantitative and qualitative variables. Explored predictors were (Table 1): (i) previous crop, (ii) sowing date (as days after September 1st for early sowings, and after November 20th for late sowings), (iii) applied phosphorus (kg $\mathrm{P} \mathrm{ha}^{-1}$; referred as applied P), (iv) soil phosphorus (ppm, $0-20 \mathrm{~cm}$ depth; referred as soil P), (v) soil $\mathrm{N}$ at planting ( $\mathrm{kg} \mathrm{N} \mathrm{ha}^{-1}, 0-60 \mathrm{~cm}$ depth) plus $\mathrm{N}$ from applied fertilizer ( $\mathrm{kg} \mathrm{N} \mathrm{ha}^{-1}$; referred as $\mathrm{N}$ availability), (vi) soil sulfur at sowing ( $\mathrm{kg} \mathrm{S}^{-1}, 0-20 \mathrm{~cm}$ depth) plus fertilizer ( $\mathrm{kg} \mathrm{S} \mathrm{ha}^{-1}$; referred as S availability), (vii) stand density at harvest ( $\mathrm{pl} \mathrm{ha}^{-1}$ ), (viii) foliar fungicide use, as a nominal variable with two levels ( 0 for no use and 1 for fungicide use at any timing during the crop cycle), (ix) presence of a water table at sowing between soil surface and $2 \mathrm{~m}$ depth, as a nominal variable ( 0 for absence and 1 for presence), (x) rainfall during the crop cycle (mm), (xi) soil water availability at sowing $(\mathrm{mm})$ until $1 \mathrm{~m}$ depth, (xii) soil type, as three levels (soil types I and II, III, and IV-V-VI), and (xiii) soil organic matter (\%, $0-20 \mathrm{~cm}$ depth).

Key concepts to consider during data exploration were outliers, multicollinearity, yield response to each variable, and potential interactions between variables (Zuur et al., 2009). Multicollinearity among quantitative variables was evaluated by matrix correlations following Pearson method, and variance inflation factor (VIF) in R (R Core Team, 2018, version 3.5.1; fmsb package; Nakazawa, 2014). Collinearity between qualitative and quantitative variables was evaluated using general linear ANOVA (agricolae package; Mendiburu, 2017). Latitude and longitude were also included in this correlation analysis as quantitative variables to explore any possible spatial trends (Table 1 ). Spatial correlation between management and environmental variables was tested with Moran test (ape package, Moran.I function; Paradis and Schliep, 2019).

\subsection{Statistical analysis and model selection}

Databases for ES and LS were treated separately. We used linear mixed-effects models to assess the influence of different predictors on grain yield for ES and LS (nlme package, lme function; Pinheiro et al., 2018). We applied the top-down strategy of model selection process (Zuur et al., 2009), similarly to Gambin et al. (2016). The top-down strategy of model selection included four steps (Zuur et al., 2009). First, we created a "beyond optimal model" that included all potential explanatory variables as fixed effects. Second, we searched for the optimal structure of the random component. Third, we searched for the optimal fixed components. And finally, if model showed an important difference when compared to the other models it was considered as the "best" model.

We started with the "beyond optimal model". This model could contain all explanatory variables and as many interactions as possible. For our case this is impractical due to the large number of explanatory variables and interactions. Then, we explored a selection of explanatory variables that evidenced a yield effect based on data exploration (Zuur et al., 2009). After data exploration, which involved graphical analysis of yield response to different predictor variables for each data set, we defined explanatory variables in the fixed component that were most likely to contribute to the optimal model for ES and LS. Each overall partial regression coefficient $(\beta+)$ was considered a fixed effect reflecting the influence of a predictor (e.g., stand density) on grain yield across all environments at each sowing date. For some variables, a second-order polynomial function $\left(Y_{i}=\alpha+\beta_{1} \times X_{i}+\beta_{2} \times X_{i}^{2}+\varepsilon_{i}\right)$ was considered, so we present models with coefficients $\beta_{1}+\beta_{2}$. Because yield predictor variables are in different scales, the analysis was

Table 1

Management and environmental variables considered in the analysis for early and late sowing dates, including type, units, and explored range. Nitrogen and sulphur availabilities are expressed in $\mathrm{kg}$ of nutrient $\mathrm{ha}^{-1}$, and represent the amount in the soil $(0-60 \mathrm{~cm})$ at sowing plus the amount added with fertilizer.

\begin{tabular}{|c|c|c|c|c|c|}
\hline \multirow[t]{2}{*}{ Variable class } & \multirow[t]{2}{*}{ Variable } & \multirow[t]{2}{*}{ Type } & \multirow[t]{2}{*}{ Units } & \multicolumn{2}{|l|}{ Explored range } \\
\hline & & & & Early sowing & Late sowing \\
\hline \multirow[t]{8}{*}{ Management } & Previous Crop & Qualitative & - & Maize, Soybean & Maize, Peanut, Soybean \\
\hline & Sowing date & Quantitative & days & September 8th - November 10th & November 27th - January 7 th \\
\hline & Applied P & Quantitative & $\mathrm{kg} \mathrm{ha}^{-1}$ & $0-41$ & $0-35$ \\
\hline & Soil P & Quantitative & ppm & $6.7-43.8$ & $5.0-46.2$ \\
\hline & $\mathrm{N}$ availability at sowing & Quantitative & $\mathrm{kg} \mathrm{ha}^{-1}$ & $149-338$ & $132-303$ \\
\hline & S availability at sowing & Quantitative & $\mathrm{kg} \mathrm{ha}^{-1}$ & $22-73$ & $18-56$ \\
\hline & Stand density & Quantitative & $\mathrm{pl} \mathrm{ha}^{-1}$ & $59,974-100,000$ & $60,000-77,000$ \\
\hline & Foliar fungicide & Qualitative & Yes/No & - & - \\
\hline \multirow[t]{7}{*}{ Environment } & Soil class & Qualitative & - & I - III & I - VI \\
\hline & Rainfall during the crop cycle & Quantitative & $\mathrm{mm}$ & $248-908$ & $218-854$ \\
\hline & Water table presence & Qualitative & Yes/No & - & - \\
\hline & Soil water at sowing & Quantitative & $\mathrm{mm}$ & $33-190$ & $56-205$ \\
\hline & Organic matter & Quantitative & $\%$ & $1.23-3.94$ & $1.49-3.44$ \\
\hline & Latitude & Quantitative & Degrees & -34.23 to -31.36 & -34.23 to -32.04 \\
\hline & Longitude & Quantitative & Degrees & -63.94 to -60.87 & -63.97 to -60.47 \\
\hline
\end{tabular}


done with standardized variables by z-scores.

The random structure for ES and LS was the same. By including block nested within genotype, and genotype nested within environment as random effects, our models estimated different intercepts for each block, genotype, and environment to account for the hierarchical data structure. For LS, heterogeneity was incorporated into the model by using the VarIdent variance structure for the variable fungicide use (Zuur et al., 2009).

Next, we searched for the optimal fixed structure following multimodel inference (MMI), based on information-theoretic approach (Burnham and Anderson, 2004). This approach does not accept the notion that there is a simple "true model" in biological sciences. Despite a "true model" could exist, we try to advance to a model that inference from our results in the simplest and most significant way, and tells us what "effects" (represented by parameters) can be supported by the data (Burnham and Anderson, 2004). Based on the context and our objectives, AIC (Akaike's information criterion) is the appropriate tool for model selection when compared to others as BIC (Bayesian's information criterion) or hypothesis testing (Aho et al., 2014; Burnham et al., 2011). Because models have different fixed effects (but similar random structure), ML (maximum likelihood) estimation was used and not REML (restricted maximum likelihood).

We calculated a weight of evidence (Akaike weight; $\omega_{i}$ ) to measure the relevance of each possible predictor (based on the relative importance, RI) for both sowing dates. The Akaike weights $\left(\omega_{\mathrm{i}}\right)$ represents the probability for a model $i$ to be the actual "best model" given a set of considered models. The $\omega_{i}$ provide an effective way to scale, and is a standardized value ranging from 0 to 1 , with the sum of $\omega_{i}$ of all models in the candidate set being 1 (Burnham and Anderson, 2004). In many contexts, the AIC selected best model will include and exclude some variables, yet this inclusion or exclusion by itself does not distinguish differential evidence of importance for all yield predictors. In consequence, RI provides a much more representative estimate of evidence for all predictors (Burnham and Anderson, 2004). The $\omega_{i}$ of all models derived from the MMI, and based on the $\omega_{\mathrm{i}}$ of all models we calculated the RI (MuMIn package, importance function; Barton, 2018).

The best model for each sowing date was obtained following a model averaging approach (Burnham and Anderson, 2004). Model averaging produces parameters that are not based on one model, but instead derived from weighted averages across multiple models based on the $\omega_{\mathrm{i}}$. These averaged estimates are a much more stabilized parameter in situations where a single best model is highly variable due to small $\triangle$ AIC (Buckland et al., 1997; Lukacs et al., 2010). There are two average versions, the first one called "full" and the second one called "natural" or "subset". The "full" considers that the yield predictor is included in all models and the estimate is set to zero when the predictor is not included. The "natural" or "subset" only averages models that included the predictor. We will refer to the "subset" model average, but estimates of the "full" model average are also described. The models included for model averaging had $\triangle$ AIC $<4$ (Burnham and Anderson, 2004).

A sensitivity analysis was made to test potential changes in our statistical model to specific environments. We used a leaving one out validation approach (Hastie et al., 2001; Arlot and Celisse, 2010), and eliminated ten extreme sites (five sites with extreme residuals, and five sites with extreme variation at the predictor level). Minor changes were observed (data not shown), and decided to describe the original analysis with all sites only.

\subsection{Yield increment after management optimization at each sowing}

We used final models to explore potential yield improvements after management optimization at each sowing date. For each predictor variable, we estimated the optimum value and the yield loss for values other than the optimum. The optimum was defined as the predictor value to obtain $90 \%$ of maximum yield from simple and quadratic linear regressions. The definition we used is related to increased yields to maximum levels for each management decision. Based on our objectives and the scope of our study we estimated optimum values regardless of the cost/benefit ratio, economic risk, and resource-use efficiency changes (Sadras and Denison, 2016). We calculated yield losses based on the difference between the yield at the optimum value of the predictor and the yield at explored levels other than the optimum. For each variable we also explored the accumulated frequency of explored values to help compare with current farmer decisions in each sowing date. To study how each specific predictor affected yield we kept all the other parameters constant. This allowed to observe each predictor effect without interactions with other predictors.

The effect of rainfall was analyzed using the El Niño-Southern Oscillation (ENSO) phases (Messina et al., 1999). For this, we used reported values of precipitation for years classified as Niño, Niña, and Neutral from a historical database from 1931 to 1997 from Pergamino, a reference city located in the study area. For ES, the considered period was September to February, with average values of 454, 590, and $641 \mathrm{~mm}$ for Niña, Neutral, and Niño years, respectively. For LS, the period ranged from December to April, with average values of 426, 549, and $580 \mathrm{~mm}$ for Niña, Neutral, and Niño years, respectively (Messina et al., 1999).

\section{Results}

\subsection{Management and environmental variation across trials and sowing dates}

Most explored management and environmental variables showed ample variation across sites, and explored comparable ranges between sowing dates (Table 1 ). Stand density, and $\mathrm{N}$ and $\mathrm{S}$ availability showed to be slightly higher in ES ( $p<0.05$; Table 1 ), and water content at sowing showed to be higher in LS ( $p<0.05$; Table 1 ). Grain yield variations across trials ranged from 107 to $17,993 \mathrm{~kg} \mathrm{ha}^{-1}$ for ES, and from 1125 to $14,583 \mathrm{~kg} \mathrm{ha}^{-1}$ for LS. Fig. 2 describes the explored grain yields across trials and sowing dates.

Multicollinearity was explored for both sowing dates. In ES, N availability, $\mathrm{S}$ availability, and stand density were higher when a foliar fungicide was applied ( $p<0.05)$. For this reason, fungicide use at ES was not considered further. The high correlation between $\mathrm{N}$ availability at sowing and stand density at ES ( $\rho=0.48 ; \mathrm{p}<0.001$; Table S2) was also evident when analyzed the variance inflation factor (VIF $>10$; Burnham and Anderson, 2004). For this reason, $\mathrm{N}$ availability at ES was excluded from the analysis. Other observed correlations were not relevant in terms of VIF, and thus all other variables were considered (Tables S2 and S3). No spatial correlation was found between management and environmental variables ( $\mathrm{p}>0.05)$.

\subsection{Model selection}

Based on data exploration, management variables that were included into "beyond optimal models" for both sowing dates were sowing date, $\mathrm{S}$ availability at sowing, and stand density. Environmental variables included water table, rainfall during the crop cycle, the interaction between them (i.e., water table $\mathrm{x}$ rainfall), and soil water at sowing. Applied P was included only at ES, while soil P, N availability, and fungicide use were included in LS (Table 2). The rest of the variables showed no clear association with yield.

Several predictors consistently appeared in the best models for each sowing date. This was the case of stand density in ES, fungicide use in LS, water table, rainfall during the crop cycle, and the interaction between rainfall and water table in both sowing dates (Table 2). For both sowing dates, the ten top models (models A to J for ES and LS; Table 2) based on AIC showed no robust differences on AIC nor $\omega_{\mathrm{i}}$, indicating the absence of a clear "best model". Nevertheless, the first ten models showed higher model accuracy (Table 2). 


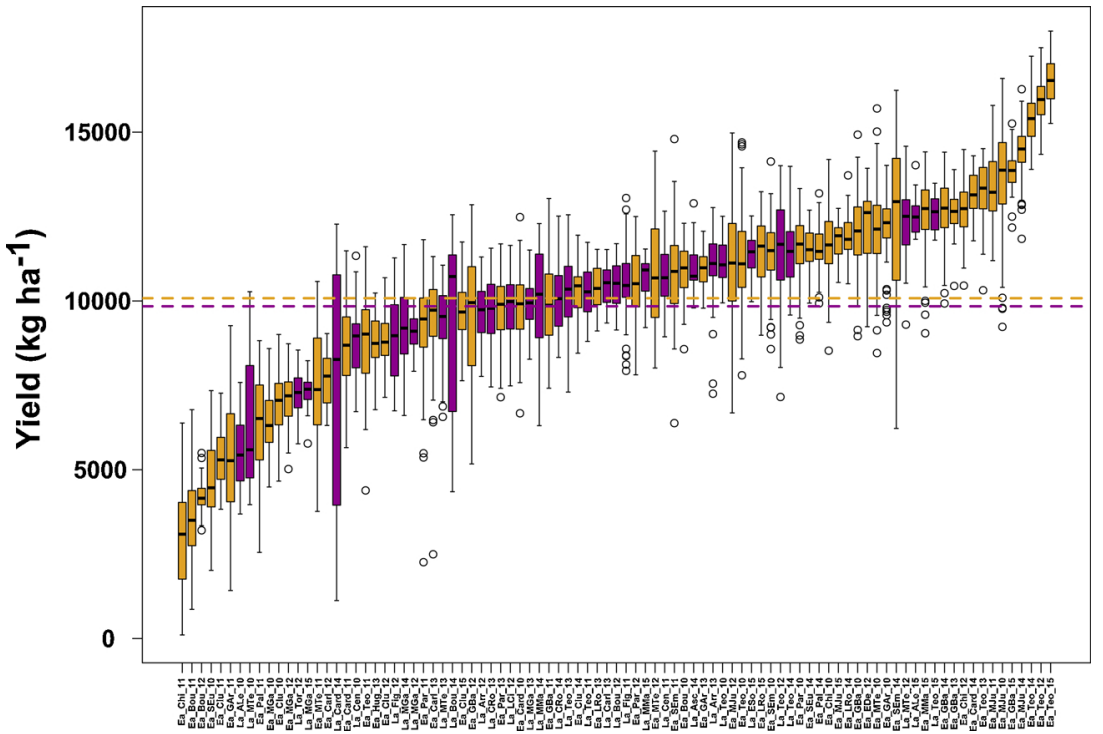

Fig. 2. Boxplot of adjusted grain yield (14\% moisture) for the analyzed 91 trials. Yellow boxplots indicate sites with early sowings, and purple one's sites with late sowings. The yellow dash line indicates the mean yield of all early sown sites $\left(10,081 \mathrm{~kg} \mathrm{ha}^{-1}\right)$ and the purple dash line the mean yield of all late sown sites $\left(9842 \mathrm{~kg} \mathrm{ha}^{-1}\right)$. Each trial had on average 16 genotypes (ranging from 8 to 32 ) sown with two or three replicates. (For interpretation of the references to colour in this figure legend, the reader is referred to the web version of this article).
We further examined the relative importance of all predictors (Table 3). The most important variables for ES were stand density and $\mathrm{N}$ availability $(\mathrm{RI}=1)$. This result highlighted the relevance of these two management variables in ES. Other management variables like $S$ availability and applied $\mathrm{P}$ followed in importance, with comparatively lower RI values (RI 0.50). For LS, the most relevant management variables $(\mathrm{RI}>0.60)$ were fungicide use, soil $\mathrm{P}$, and $\mathrm{N}$ availability. However, they all exhibited a lower RI $(\mathrm{RI}<0.70)$ when compared to the most relevant ones in ES. Environmental variables like water table and rainfall during the crop cycle showed high and comparable RI for both sowing dates (RI between 0.70 and 0.80 ), followed by the interaction between them (RI $\sim 0.50$; Table 3$)$. Soil water at sowing and sowing date showed low RI in both sowing dates (RI $<0.40$; Table 3 ). Stand density and S availability showed the lowest RI values (RI < 0.40; Table 3) among management practices in LS.

Table 2

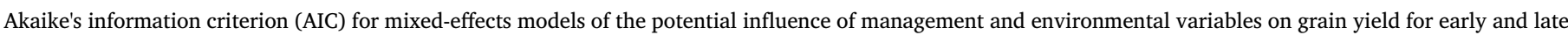

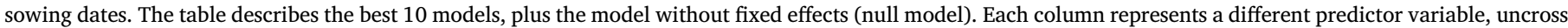

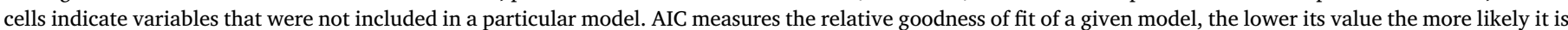

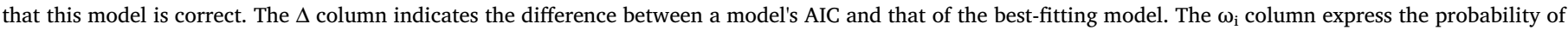

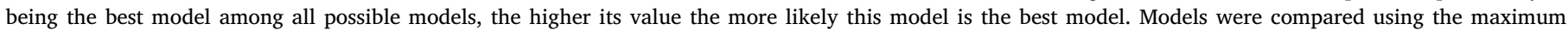
likelihood (ML) method and the same random effects. Data were standardized by z-scores prior to analysis. See materials and methods for further details.

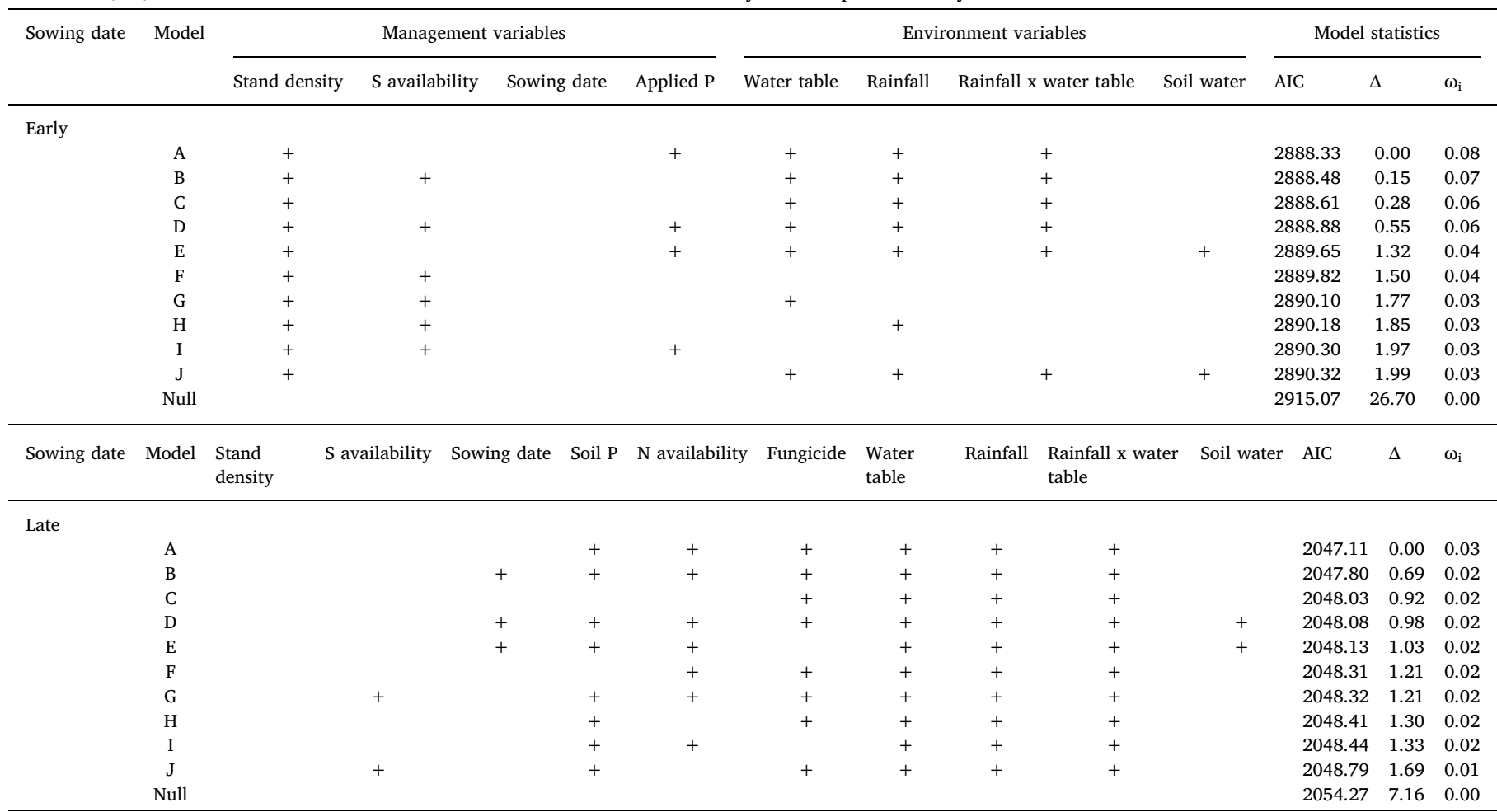


Table 3

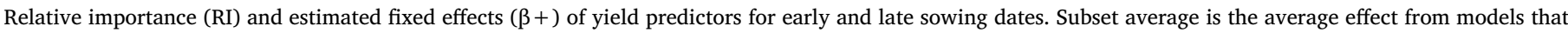

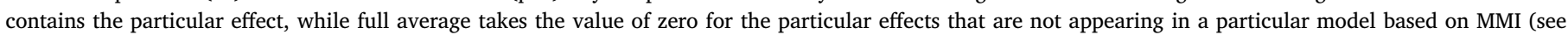
Table 2 and materials and methods for further details). Averaged estimate $\beta+$ are standardized by z-scores and non-standardized with their specific units.

\begin{tabular}{|c|c|c|c|c|c|c|c|c|}
\hline \multirow[t]{2}{*}{ Sowing date } & \multirow[t]{2}{*}{ Fixed effect } & & \multirow[t]{2}{*}{ RI } & \multicolumn{2}{|c|}{ Subset average } & \multicolumn{2}{|c|}{ Full average } & \multirow[t]{2}{*}{ Unit } \\
\hline & & & & z-scores & non-standardized & z-scores & non-standardized & \\
\hline \multicolumn{9}{|l|}{ Early } \\
\hline & Stand density & $\beta_{1}$ & 1.00 & 0.572 & 1.1 & 0.572 & 1.1 & $\mathrm{~kg} \mathrm{pl}^{-1}$ \\
\hline & & $\beta_{2}$ & & -0.053 & 0.0 & -0.053 & 0.0 & \\
\hline & Water table & & 0.75 & 0.352 & 1140 & 0.276 & 895 & $\mathrm{~kg} \mathrm{ha}^{-1}$ \\
\hline & Rainfall & & 0.70 & 0.055 & 1.2 & 0.040 & 0.9 & $\mathrm{~kg} \mathrm{ha}^{-1} \mathrm{~mm}^{-1}$ \\
\hline & S availability & $\beta_{1}$ & 0.56 & 0.216 & 206 & 0.124 & 118 & $\mathrm{~kg} \mathrm{~kg} \mathrm{~S}^{-1}$ \\
\hline & & $\beta_{2}$ & & -0.054 & -1.5 & -0.031 & -0.9 & \\
\hline & Rainfall x Water table & & 0.48 & -0.389 & -7.2 & -0.214 & -4.6 & $\mathrm{~kg} \mathrm{ha}^{-1} \mathrm{~mm}^{-1}$ \\
\hline & Applied P & & 0.46 & 0.129 & 43 & 0.058 & 19 & $\mathrm{~kg} \mathrm{~kg} \mathrm{P}^{-1}$ \\
\hline & Soil water & & 0.29 & 0.038 & 4.1 & 0.009 & 0.9 & $\mathrm{~kg} \mathrm{ha}^{-1} \mathrm{~mm}^{-1}$ \\
\hline & Planting date & $\beta_{1}$ & 0.14 & 0.042 & 74 & 0.002 & 3.7 & $\mathrm{~kg} \mathrm{ha}^{-1}$ day of delay ${ }^{-1}$ \\
\hline & & $\beta_{2}$ & & -0.044 & -1.0 & -0.002 & -0.1 & \\
\hline \multicolumn{9}{|l|}{ Late } \\
\hline & Rainfall & & 0.82 & 0.355 & 4.1 & 0.338 & 3.9 & $\mathrm{~kg} \mathrm{ha}^{-1} \mathrm{~mm}^{-1}$ \\
\hline & Water table & & 0.77 & -0.478 & -938 & -0.440 & -865 & $\mathrm{~kg} \mathrm{ha}^{-1}$ \\
\hline & Fungicide use & & 0.66 & 0.532 & 1044 & 0.395 & 776 & $\mathrm{~kg} \mathrm{ha}^{-1}$ \\
\hline & Soil P & $\beta_{1}$ & 0.61 & 0.137 & 197 & 0.095 & 136 & $\mathrm{~kg} \mathrm{ha}^{-1} \mathrm{ppm}^{-1}$ \\
\hline & & $\beta_{2}$ & & -0.326 & -3.7 & -0.225 & -2.6 & \\
\hline & $\mathrm{N}$ availability & & 0.61 & 0.214 & 10 & 0.147 & 7.1 & $\mathrm{~kg} \mathrm{~kg} \mathrm{~N}^{-1}$ \\
\hline & Rainfall $\mathrm{x}$ Water table & & 0.55 & -0.505 & -1.7 & -0.427 & -4.9 & $\mathrm{~kg} \mathrm{ha}^{-1} \mathrm{~mm}^{-1}$ \\
\hline & Soil water & & 0.37 & 0.138 & 7.9 & 0.033 & 1.9 & $\mathrm{~kg} \mathrm{ha}^{-1} \mathrm{~mm}^{-1}$ \\
\hline & Planting date & $\beta_{1}$ & 0.36 & -0.204 & 21 & -0.062 & 6.2 & $\mathrm{~kg} \mathrm{ha}^{-1}$ day of delay ${ }^{-1}$ \\
\hline & & $\beta_{2}$ & & -0.077 & -1.1 & -0.024 & -0.3 & \\
\hline & Stand density & & 0.32 & 0.046 & 0.02 & 0.008 & 0.003 & $\mathrm{~kg} \mathrm{pl}^{-1}$ \\
\hline & S availability & $\beta_{1}$ & 0.22 & 0.057 & 289 & 0.009 & 44 & $\mathrm{~kg} \mathrm{~kg} \mathrm{~S}^{-1}$ \\
\hline & & $\beta_{2}$ & & -0.136 & -3.5 & -0.021 & -0.5 & \\
\hline
\end{tabular}

\subsection{Model averaging}

A model averaging approach was used to estimate regression coefficients $(\beta+)$ for each yield predictor in each sowing date. This allowed quantifying the particular influence of each predictor variable on grain yield across several possible models (Table 3 ).

When focusing in the variables with higher RI for ES, in decreasing order, were stand density $>$ water table and its interaction with rainfall $>$ S availability $>$ applied P (Table 3). Stand density showed a positive decelerating effect on grain yield, with an average yield increase of $0.28 \mathrm{~kg} \mathrm{pl}^{-1}$ (Fig. 3A) until $90,000 \mathrm{pl} \mathrm{ha}^{-1}$. When $\mathrm{N}$ availability is analyzed (instead of stand density) the effect was $27.6 \mathrm{~kg} \mathrm{~kg}$ $\mathrm{N}^{-1}$ (Fig. 3H. Water table had a positive effect of $1140 \mathrm{~kg} \mathrm{ha}^{-1}$ (Fig. 3B) and, when present, a negative effect of rainfall was evident (-7.2 $\mathrm{kg} \mathrm{ha}^{-1} \mathrm{~mm}^{-1}$; Fig. 3C). Instead, in trials with no water table influencing the crop rainfall showed a positive yield effect of $1.2 \mathrm{~kg} \mathrm{ha}^{-1} \mathrm{~mm}^{-1}$ (Fig. 3C). Sulphur availability showed an average yield increase of $110 \mathrm{~kg} \mathrm{~kg} \mathrm{~S}^{-1}$ until $41 \mathrm{~kg} \mathrm{~S} \mathrm{ha}^{-1}$, and the yield re-

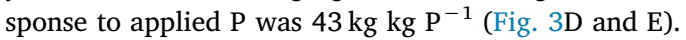

For LS, the variables with higher RI were, in decreasing order, fungicide use $>$ water table and its interaction with rainfall $>$ soil $\mathrm{P}>\mathrm{N}$ availability (Table 3). Fungicide use promoted an overall increase in grain yield of $1044 \mathrm{~kg} \mathrm{ha}^{-1}$ (Fig. 4C). Contrary to ES, water table had a negative effect on yield of $-938 \mathrm{~kg} \mathrm{ha}^{-1}$ (Fig. 4B), and in fields with an influencing water table rainfall reduced yields at a rate of $1.7 \mathrm{~kg} \mathrm{ha}^{-1} \mathrm{~mm}^{-1}$ (Fig. 4A). In the absence of a water table, rainfall had a positive yield effect of $4 \mathrm{~kg} \mathrm{ha}^{-1} \mathrm{~mm}^{-1}$ (Fig. 4A). Soil P showed a positive decelerating yield effect (Fig. 4D) with an average response of $138 \mathrm{~kg} \mathrm{ha}^{-1} \mathrm{ppm}^{-1}$ of $\mathrm{P}$ at $20 \mathrm{~cm}$ depth until $11 \mathrm{ppm}$. Nitrogen availability showed a positive yield effect (Fig. 4E) with an overall increase of $10 \mathrm{~kg} \mathrm{~kg} \mathrm{~N}^{-1}$.

In agreement with lower RI values, less important variables at both sowing dates were soil water at sowing (having a positive effect in both cases of 4.1 and $7.9 \mathrm{~kg} \mathrm{ha}^{-1} \mathrm{~mm}^{-1}$ for ES and LS, respectively; Figs. 3F and $4 \mathrm{~F}$ ) and sowing date. Sowing date presented a quadratic curve with an optimum range ( $90 \%$ of maximum yield) for both sowings. For ES, the optimum range spanned from 7th September to 6th November (Fig. 3G), and for LS the optimum ended in 30th December (Fig. 4G) with an average decrease of $80 \mathrm{~kg} \mathrm{ha}^{-1}$ day $^{-1}$ after this date. For LS, additional less important variables were stand density (with a positive effect of $0.02 \mathrm{~kg} \mathrm{pl}^{-1}$; Fig. 4H) and S availability (with an average yield response of $144 \mathrm{~kg} \mathrm{~kg} \mathrm{~S}^{-1}$ until $24 \mathrm{~kg} \mathrm{~S}^{-1}$; Fig. 4I).

\subsection{Potential yield increases with management optimization}

Estimated regression coefficients were used to explore potential yield improvements when compared to the average farmer management.

In ES, yield losses can be very important if stand density decrease from the optimum value of $90,000 \mathrm{pl} \mathrm{ha}^{-1}$ (Fig. 5A). At the average stand density currently used by farmers $\left(77,000 \mathrm{pl} \mathrm{ha}^{-1}\right)$ the yield loss is $3053 \mathrm{~kg} \mathrm{ha}^{-1}$, taking into consideration that this would be under non-limiting $\mathrm{N}$ conditions (i.e., the farmer that adds more plants also adds more N; Table S2). Forty percent of farmers used fields with no water table influencing their crops in early sowings, and they could be losing up to $1742 \mathrm{~kg} \mathrm{ha}^{-1}$ whenever rainfall levels are lower than average, but only $274 \mathrm{~kg} \mathrm{ha}^{-1}$ when rainfall levels are higher than average (Fig. 5B; Table 4).

More than $50 \%$ of farmers explored $S$ availability levels close to optimum levels in ES (41 kg S ha ${ }^{-1}$; Fig. 5C), but practically no farmer applied $\mathrm{P}$ at optimum rates (only $12 \%$ of farmers applied more than $32 \mathrm{~kg} \mathrm{P} \mathrm{ha}^{-1}$; Fig. 5D). Thus, yield gain after optimizing each nutrient would be more significant for $\mathrm{P}$ than for $\mathrm{S}$ (Figs. $4 \mathrm{C}$ and $\mathrm{D}$, respectively). The yield loss under the range of explored sowing dates in ES is low because most farmers are sowing within the optimum period for ES, and is significant when sowing date is delayed to the middle of November (up to $880 \mathrm{~kg} \mathrm{ha}^{-1}$ ).

For LS, most farmers $(70 \%)$ are losing $1044 \mathrm{~kg} \mathrm{ha}^{-1}$ for not 


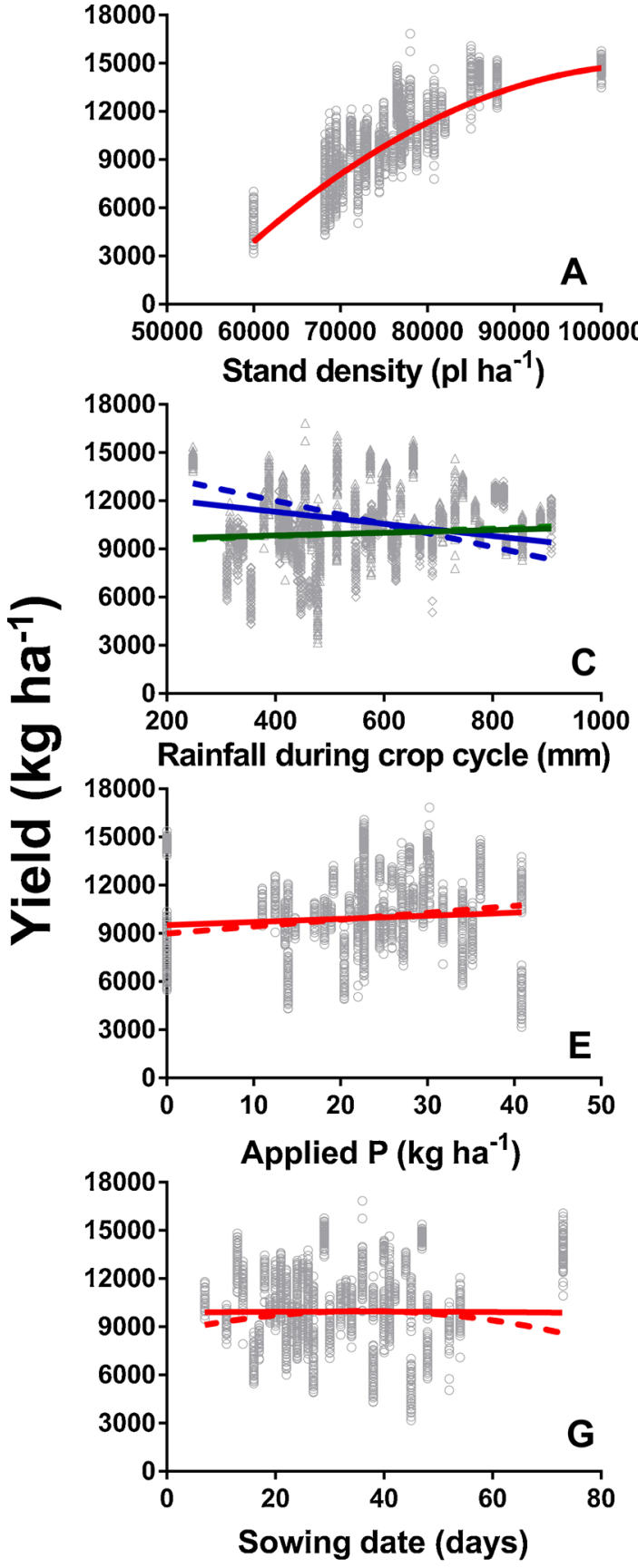

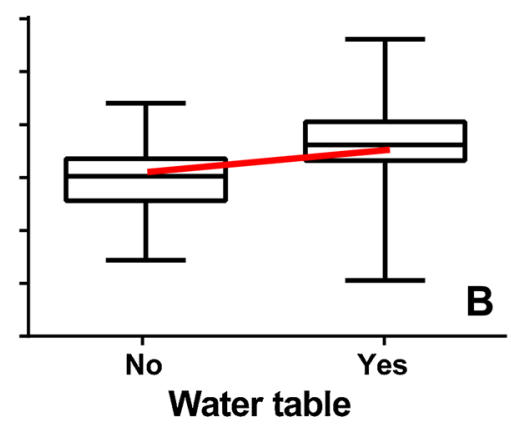
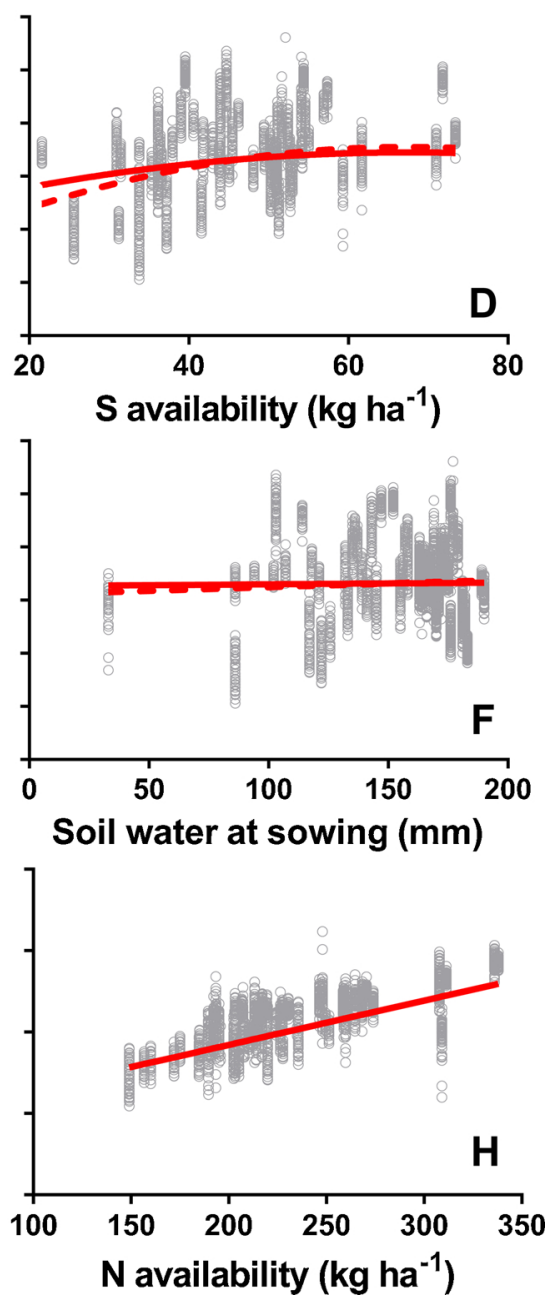

Fig. 3. Relationship between grain yield at early sowing date and stand density (Fig. 3A), water table (Fig. 3B), rainfall during the crop cycle (Fig. 3C), S availability at sowing (Fig. 3D), applied P (Fig. 3E), soil water availability at sowing (Fig. 3F), and sowing date (Fig. 3G). Fig. 3H describes the relationship between grain yield and $\mathrm{N}$ availability for early sowing. Variables are presented in order following their relative yield relevance for early sowing date (see Table 3 ). The red solid and dashed line reflects the "full averaged" and "subset averaged" $\beta+$, respectively, for stand density (Fig. 3A), water table (Fig. 3B), S availability at planting (Fig. 3D), applied $\mathrm{P}$ (Fig. 3E), soil water at sowing (Fig. 3F), and sowing date (Fig. 3G). In Fig. 3C the blue solid and dashed lines reference the "full averaged" and "subset averaged" $\beta+$, respectively, for sites with a water table influencing the crop, while the green solid and dashed lines reference the "full averaged" and "subset averaged" $\beta+$, respectively, for sites with no water table influencing the crop. In Fig. 3C empty triangles indicate sites with a water table influencing the crop, and empty squares reference sites with no water table influencing the crop. In Fig. 3G sowing date is described as days after September 1 st. (For interpretation of the references to colour in this figure legend, the reader is referred to the web version of this article). applying any foliar fungicide (Fig. 5E; Table 4). Around $30 \%$ of farmers used fields with the influence of a water table, and they could be losing up to $1367 \mathrm{~kg} \mathrm{ha}^{-1}$ if rainfall levels are higher than average, or $530 \mathrm{~kg} \mathrm{ha}^{-1}$ if rainfall levels are below average (Fig. 5F). A similar proportion of farmers are losing yield (up to $827 \mathrm{~kg} \mathrm{ha}^{-1}$ ) due to low soil $\mathrm{P}$ levels $<11 \mathrm{ppm}$. The yield loss due to $\mathrm{N}$ availability is more important (up to $1200 \mathrm{~kg} \mathrm{ha}^{-1}$ ), where practically no farmer is cropping with optimum $\mathrm{N}$ availability levels for maximum yield (only $10 \%$ of farmers have more than $250 \mathrm{~kg} \mathrm{~N} \mathrm{ha}^{-1}$; Fig. $5 \mathrm{H}$; Table 4). Stand density can also increase grain yield in LS, but the response magnitude is low (up to $187 \mathrm{~kg} \mathrm{ha}^{-1}$ when raising stand density from $64,000-75,000 \mathrm{pl} \mathrm{ha}^{-1}$; Table 4). Finally, most farmers (> $70 \%$ ) are sowing at optimum dates for LS, and explored $S$ availability levels are close to the optimum ones (Fig. 4G; Table 4).

\section{Discussion}

4.1. Most relevant yield environmental predictors are similar at both sowing dates but have contrasting effects depending on the particular sowing date

Presence of water table, rainfall during the crop cycle, and their interaction were very relevant variables affecting yield in both sowing dates. This is not surprising considering that water availability is the most relevant yield constraint in rainfed cropping systems (Hall et al., 1992). The presence of an available water table interacting with the crop had a positive effect on yield at ES, but a negative effect in LS. This contrasting response might be a consequence of the differential evaporative demand between sowing dates (Maddonni, 2012), together with the concept of an optimum water table depth. Optimum water table depth for positive maize yield effects was estimated from 1.40 to $2.45 \mathrm{~m}$ depth (Nosetto et al., 2009). Higher evaporative demand in ES 


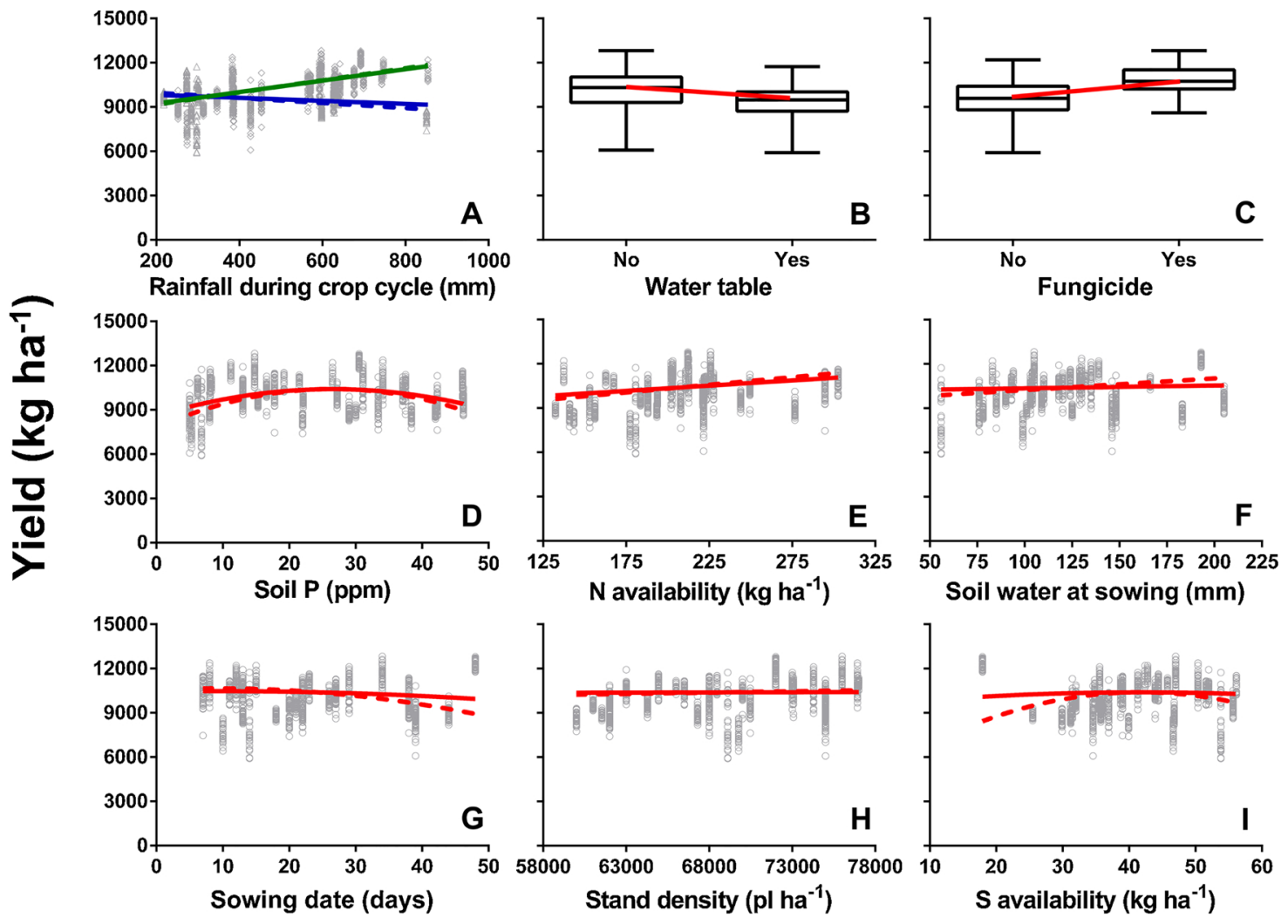

Fig. 4. Relationship between grain yield at late sowing date and rainfall during the crop cycle (Fig. 4A), water table (Fig. 4B), fungicide use (Fig. 4C), soil $P$ availability (Fig. 4D), N availability (Fig. 4E), soil water at sowing (Fig. 4F), sowing date (Fig. 4G), stand density (Fig. 4H), and S availability (Fig. 4I). Variables are presented in order following their relative yield relevance for late sowing (see Table 3). In Fig. 4A the solid and dashed lines reference the "full averaged" and "subset averaged" $\beta+$, respectively, at sites with a water table influencing the crop, while the green solid and dashed lines reference the "full averaged" and "subset averaged" $\beta+$, respectively, for sites with no water table influence. In Fig. 4A empty triangles indicate sites with the presence of a water table, while empty squares sites with no water table. In Figs. 4B, 4C, 4D, 4E, 4F, 4 G, 4H, and 4I the red solid and dashed lines reference the "full averaged" and "subset averaged" $\beta+$, respectively. In Fig. 4G sowing date is described as days after November 20th. (For interpretation of the references to colour in this figure legend, the reader is referred to the web version of this article).

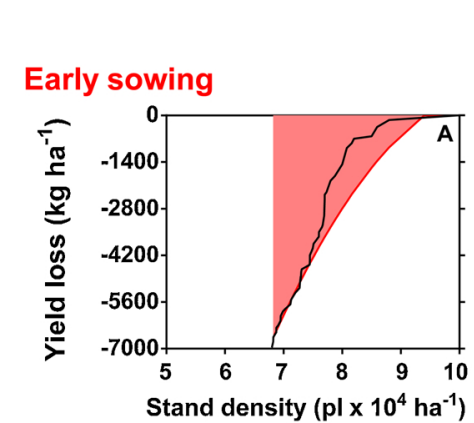

Yield loss

- Percent of total sites

\section{Late sowing}
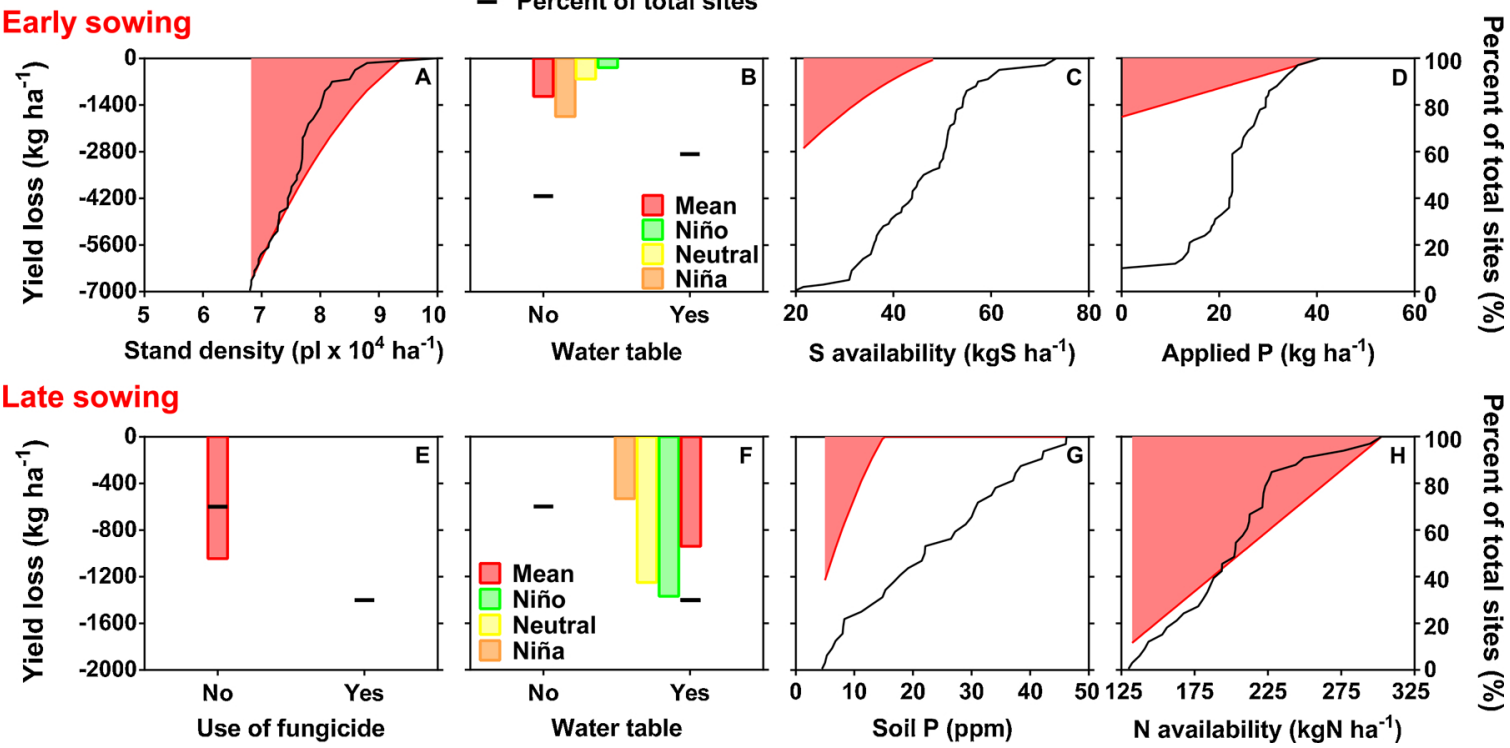

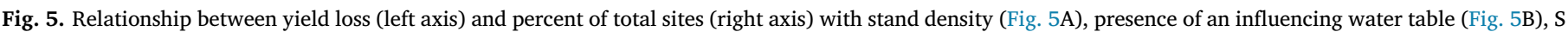

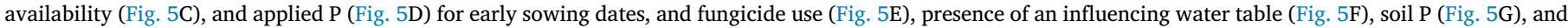

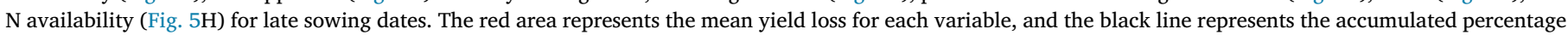

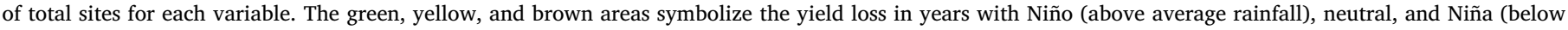

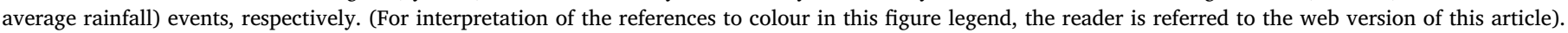


Table 4

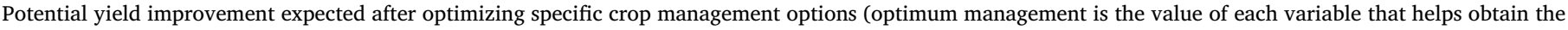

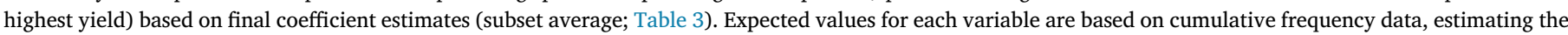

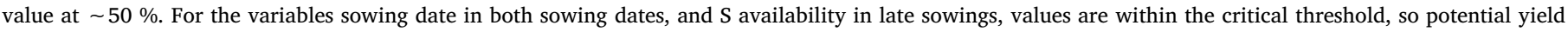
improvement should not be expected.

\begin{tabular}{|c|c|c|c|c|}
\hline \multirow[t]{2}{*}{ Sowing date } & \multirow[t]{2}{*}{ Management variable } & \multicolumn{2}{|c|}{ Values } & \multirow{2}{*}{$\begin{array}{l}\text { Yield improvement } \\
\mathrm{kg} \mathrm{ha}^{-1}\end{array}$} \\
\hline & & Expected & Optimum & \\
\hline \multirow[t]{4}{*}{ Early } & Stand density & $77,000 \mathrm{pl} \mathrm{ha}^{-1}$ & $90,000 \mathrm{pl} \mathrm{ha}^{-1}$ & 3053 \\
\hline & S availability at sowing & $45 \mathrm{~kg} \mathrm{Sha}^{-1}$ & $41 \mathrm{~kg} \mathrm{Sha}^{-1}$ & 0 \\
\hline & Applied P & $24 \mathrm{kgPha}^{-1}$ & $32 \mathrm{~kg} \mathrm{Pha}^{-1}$ & 344 \\
\hline & Sowing date & $25^{\text {th }}$ Sep & $7^{\text {th }}$ Sep to $6^{\text {th }}$ Nov & 0 \\
\hline \multirow[t]{6}{*}{ Late } & Fungicide use & No & Yes & 1044 \\
\hline & Soil P & $14 \mathrm{ppm}$ & $11 \mathrm{ppm}$ & 0 \\
\hline & $\mathrm{N}$ availability at sowing & $210 \mathrm{~kg} \mathrm{~N} \mathrm{ha}^{-1}$ & $250 \mathrm{~kg} \mathrm{Nha}^{-1}$ & 415 \\
\hline & Sowing date & $6^{\text {th }} \mathrm{Dec}$ & Until $30^{\text {th }}$ Dec & 0 \\
\hline & Stand density & $64,000 \mathrm{pl} \mathrm{ha}^{-1}$ & $75,000 \mathrm{pl} \mathrm{ha}^{-1}$ & 187 \\
\hline & S availability at sowing & $36 \mathrm{~kg} \mathrm{~S} \mathrm{ha}^{-1}$ & $24 \mathrm{~kg} \mathrm{Sha}^{-1}$ & 0 \\
\hline
\end{tabular}

could maintain water tables fluctuating around the optimum range, while lower evaporative demands in LS might result in water table levels rising above optimum levels. A negative effect of similar magnitude in LS was recently described for the same region but using an independent dataset (Gambin et al., 2016).

Also, results showed the yield effect of a higher rainfall during the growing season will depend on the presence of a water table in both sowing dates. Higher rainfall in fields with the presence of an influencing water table have yield penalties, higher yields are always evident with large amounts of rainfall in fields with no water table (Figs. 3C and 4A). High rainfall levels can increase water table levels to depths affecting maize yield ( $<1.40 \mathrm{~m}$ depth, Nosetto et al., 2009), producing temporal waterlogging, floods, and anoxic conditions (Kuppel et al., 2015; Lone and Warsi, 2009). Based on our previous study with late sown maize crops in the region (Gambin et al., 2016) the negative interaction effect of large rainfall events and the presence of a water table could be expected for LS, but the observed negative effect in ES was not. This result is suggesting that water table levels might be more frequently closer to soil surface and above the optimum depth than expected (i.e., $1.40 \mathrm{~m}$; Nosetto et al., 2009).

Regardless of sowing date, an available water table can have a positive or negative yield effect depending on its chemistry, something that was not considered in our study. It can increase yields based on nutrient provision (Portela et al., 2009) but can also decrease yields if salinization occurs (Noory et al., 2009). We did not measure any water quality parameter in our study.

Results related to the presence of water table and their interaction with rainfall have important consequences for field assignment. In fields with the presence of an influencing water table close to surface farmers should sow early, expecting higher yields at ES. In this case, only at very high rainfall levels yield penalties will exist.

\subsection{Important management yield predictors differ for early and late sowings}

Management decisions differed in relevance and effect on grain yield at ES and LS. This means that farmers need to optimize different management variables depending on the particular sowing date. Stand density and $\mathrm{N}$ availability were the most important predictors at ES, followed by $\mathrm{S}$ availability and applied P. Fungicide use, soil P, and N availability were highly relevant in LS.

Stand density is known to be an important management decision for optimizing maize grain yield (Westgate et al., 1997; Hashemi et al., 2005; Hernández et al., 2014). In our study, caution must be taken when interpreting the described response (Fig. 3A), because farmers that use higher stand densities are also prone to fertilize with more $\mathrm{N}$. The yield response to stand density need to be considered as a response to stand density plus $\mathrm{N}$ availability. In agreement to this, the magnitude of the effect was higher to other studies in the region (Sarlangue et al., 2007; Antonietta et al., 2014; Amelong et al., 2017). In spite of being a known important management practice, it is still one of the main management options farmers need to optimize for increasing yields at ES. Almost half of the analyzed sites were losing yield because they were cropped with a lower than optimum stand density.

Nitrogen management is another relevant decision when optimizing maize grain yield in central Argentina (Alvarez, 2008; Salvagiotti et al., 2011), being more important at ES than LS. The effect on yield at ES was $27.6 \mathrm{~kg}$ of grain per $\mathrm{kg}$ of $\mathrm{N}$, and, again, needs to be interpreted as the response to $\mathrm{N}$ availability under increasing levels of stand density (Fig. $3 \mathrm{H}$ ). In agreement to this, the response observed here is higher than the one reported in other studies (Barbieri et al., 2008; Albarenque et al., 2016). Sulphur availability also appears as a relevant management option at ES, suggesting the importance of a balanced nutrition at more yielding environments (Pagani et al., 2012; Salvagiotti et al., 2017). The yield response to $\mathrm{N}$ availability at LS is lower $(10.3 \mathrm{~kg} \mathrm{~kg}$ $\mathrm{N}^{-1}$ ) and comparable to levels reported earlier (Gambin et al., 2016; Coyos et al., 2018). Yield response values for LS are in agreement to the expected reductions in $\mathrm{N}$ fertilization rates in more limited environments (Salvagiotti et al., 2011). Similar to stand density, almost half of the farmers can achieve higher yields if applying more $\mathrm{N}$.

Most Argentinean agricultural systems have a long history of P exports without replenishment, causing evident decreases in soil P levels (Rubio et al., 2008; Ciampitti et al., 2011; Sainz Rozas et al., 2012). Several grain crops (soybean, wheat, and maize) follow a typical yield saturation response curve at different soil P levels (Sucunza et al., 2018). For LS, we found the same response with comparable critical Bray-P thresholds reported by other authors (11.0 vs. $12.5 \mathrm{ppm}$; Sucunza et al., 2018). The yield response to soil $\mathrm{P}$ was not observed in ES, but grain yield responded to applied P in ES with a similar response pattern than the one observed in other studies in the region (Salvagiotti et al., 2017). This might be related to the relevance of $P$ supply during early growth stages (Grant et al., 2001). At ES maize is planted with lower soil temperatures, generating lower P availability (Richardson and Simpson, 2011). This could explain the significant yield response to applied $\mathrm{P}$ at ES irrespective of soil $\mathrm{P}$ values.

The use of foliar fungicides has proved to increase yields at several environments (Paul et al., 2011; Ruffo et al., 2015; Abdala et al., 2018). The yield response depends on growing conditions and genotype (Munkvold et al., 2001; Ruffo et al., 2015). Maize sown at LS is more susceptible to foliar diseases. In our study we found an important yield response to the use of fungicides, more than two times higher than the effect recently reported by other authors (Abdala et al., 2018), but coincident with other local specific studies testing fungicide yield responses across commercial genotypes (Accame et al., 2019). Fungicide 
was more frequently used in fields having higher stand densities and nutrient availability ( $\mathrm{N}$ and $\mathrm{S}$ ) in ES, suggesting this practice is potentially relevant also in ES. Specific experiments controlling this management are necessary to confirm the effect magnitudes.

\subsection{Regional implications for reducing maize yield gaps}

Farmers need to optimize their management to their particular production environments in order to reduce yield gaps (Lobell et al., 2009). We showed there is room for specific management practices to be optimized. Our results exhibited yield gap reductions of 3397 and $1646 \mathrm{~kg} \mathrm{ha}^{-1}$ for ES and LS, respectively, after management optimization. This rejects our initial hypothesis, we expected a higher yield impact when optimizing management in LS when comparted to ES.

Thirty percent of farmers are sowing at LS in fields with the presence of an influencing water table, losing from 530 to $1367 \mathrm{~kg} \mathrm{ha}^{-1}$ depending on rainfall levels. These fields should be sown in early sowing dates, increasing yields up to $1742 \mathrm{~kg} \mathrm{ha}^{-1}$ if rainfall levels are lower than average. Management tools to decide sowing date based on the availability of a water table within a specific depth are currently available, like groundwater elevation maps (Nosetto et al., 2009), closed phreatimetric nodes (Aragón et al., 2011), or software tools (García et al., 2018). Similarly, only a small proportion of farmers applied fungicides in LS, another management option that can help increase yields. These two simple management decisions can reduce $10 \%$ (or $1140 \mathrm{~kg} \mathrm{ha}^{-1}$; average water table effect on ES) and $9 \%$ (or $1047 \mathrm{~kg} \mathrm{ha}^{-1}$; fungicide effect on LS) their specific yield gap, respectively. These two practices can also increase farmers' net income. We estimated an increase benefit around $166{\text { US } \$ \mathrm{ha}^{-1} \text { and } 123 \text { US\$ ha }}^{-1}$

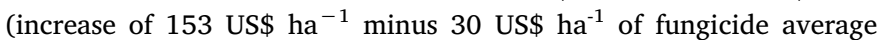
cost), respectively, based on a maize price of US\$ $146 \mathrm{tn}^{-1}$ (BCR. Bolsa de Comercio de Rosario, 2018) and their yield effect. Another direct and evident advantage is to decide the sowing date based on soil water table availability, helping stabilize maize production and reduce associated risks (Rizzo et al., 2018).

\section{Conclusions}

We described relevant specific management decisions and environmental variables using on data collected from experiments conducted with farmers' technology in farmers' fields. The analysis provided management options to help reduce yield gaps and increase the cropping efficiency of early and late sown maize crops. Management decisions related to stand density $\left(\sim 0.28 \mathrm{~kg} \mathrm{pl}^{-1}\right), \mathrm{N}$ availability $\left(27.6 \mathrm{~kg} \mathrm{~kg} \mathrm{~N}^{-1}\right)$, and $\mathrm{S}$ availability $\left(\sim 110 \mathrm{~kg} \mathrm{~kg} \mathrm{~S}^{-1}\right)$ can help increase yields in early sowing dates. Fungicide use $\left(\sim 1044 \mathrm{~kg} \mathrm{ha}^{-1}\right)$, soil $\mathrm{P}$ $\left(\sim 140 \mathrm{~kg} \mathrm{ppm}^{-1}\right.$, until $\left.11 \mathrm{ppm} \mathrm{P}\right)$, and $\mathrm{N}$ availability $\left(10 \mathrm{~kg} \mathrm{~kg} \mathrm{~N}^{-1}\right)$ are relevant management options to reduce yield gaps in late sown crops.

Environmental variables such us rainfall presented a dissimilar effect depending on the presence or absence of an influencing water table, but of similar trend for both sowing dates. The combination of an influencing water table and excessive rainfalls reduced crop yield always, suggesting that water availability is in excess when the combination of these two variables are present.

Adequate sowing date for each field paddock needs to consider the presence or absence of an influencing water table at sowing. It shows a contrasting effect depending on the sowing date. A positive effect was found for early sown maize $\left(1140 \mathrm{~kg} \mathrm{ha}^{-1}\right)$, and the negative effect described in an independent earlier study for later sowings (Gambin et al., 2016) was also detected here $\left(-938 \mathrm{~kg} \mathrm{ha}^{-1}\right)$.

\section{CRediT authorship contribution statement}

Lucas N. Vitantonio-Mazzini: Data curation, Formal analysis, Methodology, Visualization, Writing - original draft. Lucas Borrás:
Conceptualization, Writing - review \& editing, Funding acquisition. Lucas A. Garibaldi: Methodology, Formal analysis. Diego H. Pérez: Funding acquisition, Data curation. Santiago Gallo: Funding acquisition, Data curation. Brenda L. Gambin: Methodology, Formal analysis, Writing - review \& editing.

\section{Declaration of Competing Interest}

The authors declare they have no known competing financial interest or personal relationship that influenced the work reported in this paper.

\section{Acknowledgements}

Authors wish to thank CREA agronomists and farmers for technical assistance and for providing fields for experimentation. LN VitantonioMazzini held a graduate scholarship from CONICET. The study was funded by CREA Sur de Santa Fe and CONICET (grant PUE0043).

\section{Appendix A. Supplementary data}

Supplementary data associated with this article can be found, in the online version, at https://doi.org/10.1016/j.fcr.2020.107779.

\section{References}

Abdala, L.J., Gerde, J.A., Gambin, B.L., Borrás, L., 2018. Fungicide applications and grain dry milling quality in late-sown maize. Crop Sci. 58, 892-899.

Accame, F., Madias, A., Borrás, L., Gambín, B.L., 2019. Comportamiento sanitario y respuesta a la aplicación de fungicida en genotipos de maíz en fecha de siembra tardía en la Región Pampeana (in Spanish). Red Maíz Tardío AAPRESID 2018-2019 42. (Accessed October 2019). www.aapresid.org.ar/sistemachacras/revista-red-de-maiztardio-2018-2019/.

Aho, K., Derryberry, D., Peterson, T., 2014. Model selection for ecologists: the worldviews of AIC and BIC. Ecology 95, 631-636.

Albarenque, S.M., Basso, B., Caviglia, O.P., Melchiori, R.J.M., 2016. Spatio-temporal nitrogen fertilizer response in maize: field study and modeling approach. Agron. J. 108, 2110-2122.

Alvarez, R., 2008. Analysis of yield response variability to nitrogen fertilization in experiments performed in the Argentine Pampas. Commun. Soil Sci. Plant Anal. 39, $1235-1244$.

Amelong, A., Hernández, F., Novoa, A.D., Borrás, L., 2017. Maize stand density yield response of parental inbred lines and derived hybrids. Crop Sci. 57, 32-39.

Andrade, F.H., Vega, C., Uhart, S., Cirilo, A., Cantarero, M., Valentinuz, O., 1999. Kernel number determination in maize. Crop Sci. 39, 453-459.

Antonietta, M., Fanello, D.D., Acciaresi, H.A., Guiamet, J.J., 2014. Senescence and yield responses to plant density in stay green and earlier-senescing maize hybrids from Argentina. Field Crops Res. 155, 111-119.

Aragón, R., Jobbágy, E.G., Viglizzo, E.F., 2011. Surface and groundwater dynamics in the sedimentary plains of the Western Pampas (Argentina). Ecohydrol. 4, 433-447.

Aramburu Merlos, F., Monzon, J.P., Mercau, J.L., Taboada, M., Andrade, F.H., Hall, A.J., Jobbagy, E., Cassman, K.G., Grassini, P., 2015. Potential for crop production increase in Argentina through closure of existing yield gaps. Field Crops Res. 184, 145-154.

Arlot, S., Celisse, A., 2010. A survey of cross-validation procedures for model selection. Stat. Surv. 4, 40-79.

Barbieri, P.A., Echeverría, H.E., Saínz Rozas, H.R., Andrade, F.H., 2008. Nitrogen use efficiency in maize as affected by nitrogen availability and row spacing. Agron. J. 100, 1094-1100.

Barton, K., 2018. MuMIn: Multi-Model Inference. R Package Version 1.42.1. https:// CRAN.R-project.org/package $=$ MuMIn

BCR. Bolsa de Comercio de Rosario, 2018. Precios Históricos. Maíz. Available in. https://www.bcr.com.ar/Pages/Granos/Historicos/default.aspx.

Black, C.A., 1965. Methods of Soil Analysis: Part I. Physical and Mineralogical Properties. ASA, Madison, WI.

Boote, K.J., Jones, J.W., Pickering, N.B., 1996. Potential uses and limitations of crop models. Agron, J. 704-716.

Buckland, S.T., Burnham, K.P., Augustin, N.H., 1997. Model selection: an integral part of inference. Biometrics 53, 603-618.

Burnham, K.P., Anderson, D.R., 2004. Model Selection and Multimodel Inference: a Practical Information-theoretic Approach, 2nd ed. Springer Science and Business Media.

Burnham, K.P., Anderson, D.R., Huyvaert, K.P., 2011. AIC model selection and multimodel inference in behavioral ecology: some background, observations, and comparisons. Behav. Ecol. Sociobiol. 65, 23-35.

Calviño, P.A., Andrade, F.H., Sadras, V.O., 2003. Maize yield as affected by water availability, soil depth, and crop management Agron. J. 95, 275-281.

Caviglia, O.P., Melchiori, R.J.M., Sadras, V.O., 2014. Nitrogen utilization efficiency in 
maize as affected by hybrid and $\mathrm{N}$ rate in late-sown crops. Field Crops Res. 168, $27-37$.

Cerrato, M.E., Blackmer, A.M., 1990. Comparison of models for describing corn yield response to nitrogen fertilizer. Agron. J. 82, 138-143.

Ciampitti, I.A., García, F.O., Picone, L.I., Rubio, G., 2011. Phosphorus budget and soil extractable dynamics in field crop rotations in mollisols. Soil Sci. Soc. Am. J. 75, $131-142$.

Cirilo, A.G., Andrade, F.H., 1994. Sowing date and maize productivity: I. Crop growth and dry matter partitioning. Crop Sci. 34, 1039-1043.

Coyos, T., Borrás, L., Gambin, B.L., 2018. Site-specific covariates affecting yield response to Nitrogen of late-sown maize in central Argentina. Agron. J. 110, 1-10.

DeLacy, I.H., Basford, K.E., Cooper, M., Bull, J.K., McLaren, C.G., 1996. Analysis of multienvironment trials - an historical perspective. In: Cooper, M., Hammer, G.L. (Eds.), Plant Adaptation and Crop Improvement. CAB International, Wallingford, UK, pp. 39-124.

Florio, E.L., Mercau, J.L., Jobbágy, E.G., Nosetto, M.D., 2014. Interactive effects of watertable depth, rainfall variation, and sowing date on maize production in the Western Pampas. Agric. Water Manage. 146, 75-83.

Foley, J.A., Ramankutty, N., Brauman, K.A., Cassidy, E.S., Gerber, J.S., Johnston, M., Mueller, N.D., O'Connell, C., Ray, D.K., West, P.C., Balzer, C., Bennett, E.M., Carpenter, S.R., Hill, J., Monfreda, C., Polasky, P., Rockström, J., Sheehan, J., Siebert, S., Tilman, D., Zaks, D.P.M., 2011. Solutions for a cultivated planet. Nature 478, 337-342.

Gambin, B.L., Coyos, T., Di Mauro, G., Borrás, L., Garibaldi, L.A., 2016. Exploring genotype, management, and environmental variables influencing grain yield of late-sown maize in central Argentina. Agric. Syst. 146, 11-19.

García, G.A., García, P.E., Rovere, S.L., Bert, F.E., Schmidt, F., Menéndez, A., Nosetto, M.D., Verdin, A., Rajagopalan, B., Arora, P., Podestá, G.P., 2018. A linked modelling framework to explore interactions among climate, soil water, and land use decisions in the Argentine Pampas. Environ. Model. Softw. 111, 459-471.

Grant, C.A., Flaten, D.N., Tomasiewicz, D.J., Sheppard, S.C., 2001. The importance of early season phosphorus nutrition. Can. J. Plant Sci. 81, 211-224.

Hall, A.J., Rebella, C.M., Ghersa, C.M., Culot, J.P., 1992. Field-crop systems of the Pampas. In: Pearson, C.J. (Ed.), Field Crop Ecosystems. Elsevier, Amsterdam, pp. 413-450.

Hammer, G.L., McLean, G., Chapman, S., Zheng, B., Doherty, A., Harrison, M.T., van Oosterom, E., Jordan, D., 2014. Crop design for specific adaptation in variable dryland production environments. Crop Pasture Sci. 65, 614-626.

Hashemi, A.M., Helbert, S.J., Putnam, D.H., 2005. Yield response of corn to crowding stress. Agron. J. 97, 839-846.

Hastie, T., Tibshirani, R., Friedman, J.H., 2001. The Elements of Statistical Learning: Data Mining, Inference, and Prediction. Springer, New York.

Hatfield, J.L., Walthall, C.L., 2015. Meeting global food needs: realizing the potential via genetics $\times$ environment $\times$ management interactions. Agron. J. 107, 1215-1226.

Hernández, F., Amelong, A., Borrás, L., 2014. Genotypic differences among Argentinean maize hybrids in yield response to stand density. Agron. J. 106, 2316-2324.

Klingebiel, A.A., Montgomery, P.H., 1961. Agriculture handbook No. 210. Land-capability Classification. Soil Conservation Service. USDA.

Kuppel, S., Houspanossian, J., Nosetto, M.D., Jobbagy, E.G., 2015. What does it take to flood the Pampas?: Lessons from a decade of strong hydrological fluctuations. Water Resour. Res. 51, 2937-2950.

Lobell, D.B., Cassman, K.G., Field, C.B., 2009. Crop yield gaps: their importance, magnitudes, and causes. Annu. Rev. Environ. Resour. 34, 1-26.

Lone, A.A., Warsi, M., 2009. Response of maize (Zea mays L.) to excess soil moisture (ESM) tolerance at different stages of life cycle. Bot. Res. Int. 2, 211-217.

Lukacs, P.M., Burnham, K.P., Anderson, D.R., 2010. Model selection bias and Freedman's paradox. Ann. I. Stat. Math. 62, 117-125.

Maddonni, G.A., 2012. Analysis of the climatic constraints to maize production in the current agricultural region of Argentina - a probabilistic approach. Theor. Appl. Climatol. 107, 325-345.

Maltese, N.E., Melchiori, R., Maddonni, G.A., Ferreyra, J.M., Caviglia, O.P., 2019. Nitrogen economy of early and late-sown maize crops. Field Crops Res. 231, 40-50.

Mendiburu, F.D., 2017. Agricolae: Statistical Procedures for Agricultural Research. R Package Version 1.2-8. http://CRAN.R-project.org/package= agricolae.

Mercau, J.L., Otegui, M.E., 2014. A modeling approach to explore water management strategies for late-sown maize and double-cropped wheat-maize in the rainfed Pampas region of Argentina. In: Ahuja, L.R., Ma, L., Lascano, R.J. (Eds.), Practical Applications of Agricultural System Models to Optimize the Use of Limited Water, Adv. Agric. Syst. Model. 5. ASA, CSSA, and SSSA, Madison, WI, pp. 351-374.

Messina, C.D., Hansen, J.W., Hall, A.J., 1999. Land allocation conditioned on el ninosouthern oscillation phases in the pampas of Argentina. Agric. Syst. 60, 197-212.

Munkvold, G.P., Martinson, C.A., Shriver, J.M., Dixon, P.M., 2001. Probabilities for profitable fungicide use against gray leaf spot in hybrid maize. Phytopathology 91 $477-484$.
Nakazawa, M., 2014. fmsb: Functions for Medical Statistics Book with Some Demographic Data. R Package Version 0.5.1. http://CRAN.R-project.org/package $=$ fmsb.

Noory, H., Liagat, A.-M., Chaichi, M.R., Parsinejad, M., 2009. Effects of water table management on soil salinity and alfalfa yield in a semi-arid climate. Irrig. Sci. 27, 401-407.

Nosetto, M.D., Jobbágy, E.G., Jackson, R.B., Sznaider, G.A., 2009. Reciprocal influence of crops and shallow ground water in sandy landscapes of the Inland Pampas. Field Crop. Res. 113, 138-148.

Otegui, M.E., Ruiz, R.A., Petruzzi, D., 1996. Modeling hybrid and sowing date effects on potential grain yield of maize in a humid temperate region. Field Crop. Res. 47, $167-174$.

Pagani, A., Echeverría, H.E., Andrade, F.H., Sainz Rozas, H.R., 2012. Effects of nitrogen and sulfur application on grain yield, nutrient accumulation, and harvest indexes in maize. J. Plant Nutr. 5, 1080-1097.

Paradis, E., Schliep, K., 2019. ape 5.0: An environment for modern phylogenetics and evolutionary analyses in R. Bioinformatics 35, 526-528.

PAS. Panorama Agrícola Semanal, 2018. Bolsa de Cereales, Argentina. Available in. https://www.bolsadecereales.org.

Passioura, J.B., 1996. Simulation models: science, snake oil, education, or engineering? Agron. J. 88, 690-694.

Paul, P.A., Madden, L.V., Bradley, C.A., Robertson, A.E., Munkvold, G.P., Shaner, G., Wise, K.A., Malvick, D.K., Allen, T.W., Grybauskas, A., Vincelli, P., Esker, P., 2011. Meta-analysis of yield response of hybrid field corn to foliar fungicides in the U.S. corn belt. Phytopathology 101, 1122-1132.

Pinheiro, J., Bates, D., DebRoy, S., Sarkar, D., 2018. Nlme: Linear and Nonlinear Mixed Effects Models. R Package Version 3.1-137. https://CRAN.R-project.org/package= nlme.

Podestá, G.P., Messina, C.D., Grondona, M.O., Magrin, G.O., 1999. Associations between grain crop yields in central-eastern Argentina and El Niño-Southern Oscillation. J. Appl. Meteorol. Clim. 38, 1488-1498.

Portela, S.I., Andriulo, A.E., Jobbágy, E.G., Sasal, M.C., 2009. Water and nitrate exchange between cultivated ecosystems and groundwater in the Rolling Pampas. Agric. Ecosyst. Environ. 134, 277-286.

R Core Team, 2018. R: a Language and Environment for Statistical Computing. R Foundation for Statistical Computing, Vienna, Austria. http://www.R-project.org/).

Richardson, A.E., Simpson, R.J., 2011. Soil microorganisms mediating phosphorus availability update on microbial phosphorus. Plant Physiol. 156, 989-996.

Rizzo, G., Rattalino Edreira, J.I., Archontoulis, S.V., Yang, H.S., Grassini, P., 2018. Do shallow water tables contribute to high and stable maize yields in the US Corn Belt? Glob. Food Secur. 18, 27-34.

Rubio, G., Cabello, M.J., Gutiérrez Boem, F.H., Munaro, E., 2008. Estimating available soil phosphorus increases after phosphorus additions in Mollisols. Soil Sci. Soc. Am. J. $72,1721-1727$.

Ruffo, M.L., Gentry, L.F., Henninger, A.S., Seebauer, J.R., Below, F.E., 2015. Evaluating management factor contributions to reduce corn yield gaps. Agron. J. 107, 495-505.

Sadras, V.O., Denison, R.F., 2016. Neither crop genetics nor crop management can be optimised. Field Crop. Res. 189, 75-83.

Sainz Rozas, H.R., Echeverría, H.E., Angelini, H., 2012. Fósforo disponible en suelos agrícolas de la región Pampeana y extra Pampeana Argentina (in Spanish). Rev. Inv. Agric. 38, 33-39.

Salvagiotti, F., Catellarín, J.M., Ferraguti, F.J., Pedrol, H.M., 2011. Dosis óptima económica de nitrógeno en maíz según potencial de producción y disponibilidad de nitrógeno en la región pampeana norte (in Spanish). Ciencia del Suelo 29, 199-212.

Salvagiotti, F., Prystupa, P., Ferraris, G., Couretot, L., Magnano, L., Dignani, D., Gutiérrez BGutiérrez-Boemoem, F.H., 2017. N:P:S stoichiometry in grains and physiological attributes associated with grain yield in maize as affected by phosphorus and sulfur nutrition. Field Crops Res. 203, 128-138.

Sarlangue, T., Andrade, F.H., Calviño, P.A., Purcell, L.C., 2007. Why do maize hybrids respond differently to variations in plant density? Agron. J. 99, 984-991.

Soil Survey Staff, 2014. Keys to Soil Taxonomy, 12th ed. USDA-NRCS, Washington, DC.

Sucunza, F.A., Gutierrez Boem, F.H., Garcia, F.O., Boxler, M., Rubio, G., 2018. Long-term phosphorus fertilization of wheat, soybean and maize on Mollisols: soil test trends, critical levels and balances. Eur. J. Agron. 96, 87-95.

Walkley, A., Black, A., 1934. An examination of the Degtjareff method for determining soil organic matter, and proposed modification of the chromic acid titration method. Soil Sci. 37, 29-38.

Westgate, M.E., Forcella, F., Reicosky, D.C., Somsen, J., 1997. Rapid canopy closure for maize production in the northern US corn belt: radiation-use efficiency and grain yield. Field Crops Res. 49, 249-258.

Williams, W.A., Loomis, R.S., Duncan, W.G., Dovrat, A., Nunez, A.F., 1968. Canopy architecture at various population densities and the growth and grain yield of corn. Crop Sci. 8, 303-308.

Zuur, A.F., Ieno, E.N., Walker, N.J., Saveliev, A.A., Smith, G.M., 2009. Mixed Effects Models and Extensions in Ecology with R. Springer, New York. 